\title{
Assessing Intestinal Health. In Vitro and Ex vivo Gut Barrier Models of Farm Animals: Benefits and Limitations
}

\section{OPEN ACCESS}

Edited by:

Kyle R. McLeod,

University of Kentucky, United States

Reviewed by:

Guillermo Tellez,

University of Arkansas, United States

Kyung-Woo Lee,

Konkuk University, South Korea

Toshiro Arai,

Nippon Veterinary and Life Science University, Japan

XiMa,

China Agricultural University, China

*Correspondence:

Ester Grilli

ester.grill@unibo.it

Specialty section:

This article was submitted to Animal Nutrition and Metabolism,

a section of the journal

Frontiers in Veterinary Science

Received: 10 June 2021 Accepted: 01 November 2021 Published: 23 November 2021

Citation:

Ghiselli F, Rossi B, Piva A and Grilli E (2021) Assessing Intestinal Health. In Vitro and Ex vivo Gut Barrier Models of Farm Animals: Benefits and Limitations. Front. Vet. Sci. 8:723387. doi: 10.3389/fvets.2021.723387

\author{
Federico Ghiselli ${ }^{1}$, Barbara Rossi ${ }^{2}$, Andrea Piva ${ }^{1,2}$ and Ester Grilli ${ }^{1,3 *}$ \\ ${ }^{1}$ Servizio Produzioni Animali e Sicurezza Alimentare, Dipartimento di Scienze Mediche Veterinarie, University of Bologna, \\ Bologna, Italy, ${ }^{2}$ Vetagro S.p.A., Reggio Emilia, Italy, ${ }^{3}$ Vetagro Inc., Chicago, IL, United States
}

Animal performance is determined by the functionality and health of the gastrointestinal tract (GIT). Complex mechanisms and interactions are involved in the regulation of GIT functionality and health. The understanding of these relationships could be crucial for developing strategies to improve animal production yields. The concept of "gut health" is not well defined, but this concept has begun to play a very important role in the field of animal science. However, a clear definition of GIT health and the means by which to measure it are lacking. In vitro and ex vivo models can facilitate these studies, creating well-controlled and repeatable conditions to understand how to improve animal gut health. Over the years, several models have been developed and used to study the beneficial or pathogenic relationships between the GIT and the external environment. This review aims to describe the most commonly used animals' in vitro or ex vivo models and techniques that are useful for better understanding the intestinal health of production animals, elucidating their benefits and limitations.

Keywords: intestinal health, gut barrier, farm animal, ex vivo model, in vitro model

\section{INTRODUCTION}

Intestinal health is a complex concept, and several biological and mechanical factors and structures interact to affect intestinal health (1). The gut barrier is one of the main components, but there is no assay or model to completely and accurately recreate the thousands of interactions that occur in the gastrointestinal tract (GIT). In vitro and ex vivo models can be a simplified and controlled way to clarify specific interactions that involve the GIT barrier. There is a direct relationship between animal performance and a "healthy" gastrointestinal tract, but there is no clear definition of "gut health" (2). Proper nutrient digestion and absorption, a stable microbiome, good mucus layer development, and barrier function, and mucosal immune responses are the main functions of a healthy intestine. In particular, the gut epithelium is constantly exposed to foreign antigens and microorganisms. A healthy intestinal barrier allows the maintenance of mucosal immune homeostasis and prevents the onset of uncontrolled inflammation, which can lead, in the worst-case scenario, to death (3). The GIT barrier also plays a crucial role in maintaining a homeostatic relationship with immune cells and the microbiota. Intestinal epithelial cells are influenced by the microbial environment and can produce molecules, such as cytokines or chemokines, antimicrobial peptides, and hormones $(4,5)$. The gut microbiota also interacts with the host immune system largely through the gut-associated lymphoid tissue system $(6,7)$, and in many ways, the immune system can distinguish good bacteria from foes. The enteric nervous system (ENS) is also important 
for maintaining homeostasis and it is involved in the hostmicrobiome response. It helps with peristalsis in the gut, hormone secretion, neurotransmitter release, and signaling to the central nervous system (8).

The intestine is a very complex organ in which different components achieve distinct physiological functions in a highly integrated and regulated fashion. Relationships involve a complex network of hormones and cross-talk between cells in all the compartments. In vitro and ex vivo models are required to get a full description and understanding of the mechanisms and relationships between the various components. Understanding the mechanisms and interactions that affect intestinal health would be the key to find new strategies to improve animal production yields and welfare. Wu et al. (9), for example, provided an extensive review about the endogenous host defense peptides and they analyzed how them can influence the intestinal health of animals. Moreover, they also analyzed how these peptides can be used as antibiotic alternatives. In vitro or ex vivo models are also needed to reduce the ethical issues and expenses associated with the use of animals in experiments (10). In this context the 3Rs approach (11) is very useful for aiming at "Replace" animals used in experiments with non-sentient alternatives; "Reduce" the number of animals employed; and "Refine" animal experiments to cause minimum distress and pain. An ideal animal model to study gut health should contain all the gut epithelial cell types of the animal considered in the study, and these cells should have the ability to be cultured for the defined assay time without losing their in vivo characteristics. Then, the model should also represent the biochemical environment that comprises the epithelium/immune system or ENS crosstalk. In vitro models can create well-controlled and repeatable conditions with some limitations. Instead, ex vivo models refer to experiments conducted in or on the tissue directly derived from animals (12) but with a shorter lifespan and less reproducibility.

For human models, significant work has been done. Costa et al. (13) have well summarized the current methodologies used to develop human intestinal in vitro models and analyzed the future perspective. Are these models available for farm animals? It is possible to recreate the animal counterpart?

As for as farm animals, a few models and cell lines are available. Different techniques and intestinal models to mimic the animal in vivo conditions have been developed over the years (12), but the development of more complex systems could be the key to better understand animal intestinal physiology and find ways to improve animal welfare, intestinal health, and production yields. This review aimed to analyze and clarify the benefits and limitations of the main in vitro or ex vivo models available for farm animals and the techniques useful to understand the

Abbreviations: BIEC, Bovine intestinal epithelial cell; cIECs, Chicken intestinal epithelial cells; ENS, Enteric nervous system; FBCECs, Fetal bovine colon epithelial cells; GIT, Gastrointestinal tract; IF, Immunofluorescence; ISC, Short circuit current; PoCo83-3, Porcine colonic epithelial cells; PCP, Paracellular permeability; TEER, Transepithelial electrical resistance; TJs, Tight junctions; ZO1, Zonula occludens 1. relationships between animal intestinal health and gut barrier, clarifying their benefits and limitations.

\section{IN VITRO CELL-BASED MODELS}

To study animal gut barrier health, it is important to have a standardized method that can assess the functionality of this barrier (14). Permeable membranes are the most common supports used to replicate the intestinal barrier configuration (15). This system grants access to both the apical and basolateral compartments. Cells create the intestinal barrier, growing as a monolayer on a permeable membrane (i.e., Transwell $($ filters), and with this approach, it is possible to mimic the in vivo intestinal barrier physiology and functionality (16). In Figure 1 the different ways to create an in vitro model are summarized.

Caco-2 cells are the "gold standard" model for in vitro intestinal barrier assays, even for animals (17). These cells are derived from a human colorectal carcinoma (18), and at the early stage of culture, they are undifferentiated. When confluent, they form a polarized monolayer joined by tight junctions (TJs), and they express apical microvilli $(17,19,20)$. Differentiated Caco- 2 cells have most of the morphological and functional characteristics of absorptive intestinal cells, despite their colonic origin (21). These cells do not produce mucus, and they create a replicable population among studies (22). The relatively wide variation of different culture conditions, protocols, or genetic drift could be a disadvantage, but currently, efforts are being made to reproduce the same cell culture conditions to allow the usage of Caco- 2 cells as intestinal barrier models among different laboratories $(15,20)$. Caco-2 cells differentiate into mature enterocytes in 14 to 21 days if cultured on permeable support (20). Researchers have made many attempts to improve the culture protocols and reduce the differentiation times. Chong et al. (23) claimed that using a BioCoat $\AA$ intestinal epithelial-cell environment, they obtained a Caco-2 monolayer suitable to be an absorption model in only 3 days. Lentz et al. (24) also developed a rapid culture protocol in which iron, different growth factors, and hormones were added to the culture media cells, causing them to differentiate in only 4 days. In 2014, Cai et al. (25) reported that Caco- 2 cells cultured on a three-dimensional extracellular matrix substrate using an optimized serum-free medium (containing butyric acid and MITO $囚$ ) could differentiate in 7 days. These cells displayed comparable cellular morphology and integrity as the traditional 21-day model without significant differences in para-cellular and trans-cellular permeability. However, the human cancer origin of Caco-2 led researchers to isolate and immortalize some intestinal epithelial cell lines from common production animals that can grow on permeable supports and could allow us to better understand the effect of natural bioactive compounds on the animal intestine.

\section{Cell Lines for Production Animals}

Cell lines derived from the intestine of farm animals are rarely available. Moreover, the identity of farm animal cell lines is not so clear. For example, chicken B6 and B10XI cell lines have been identified as porcine cells, and IPEC (an apparent subclone of the IPEC-J2) is now assumed to be derived from cattle (26). 


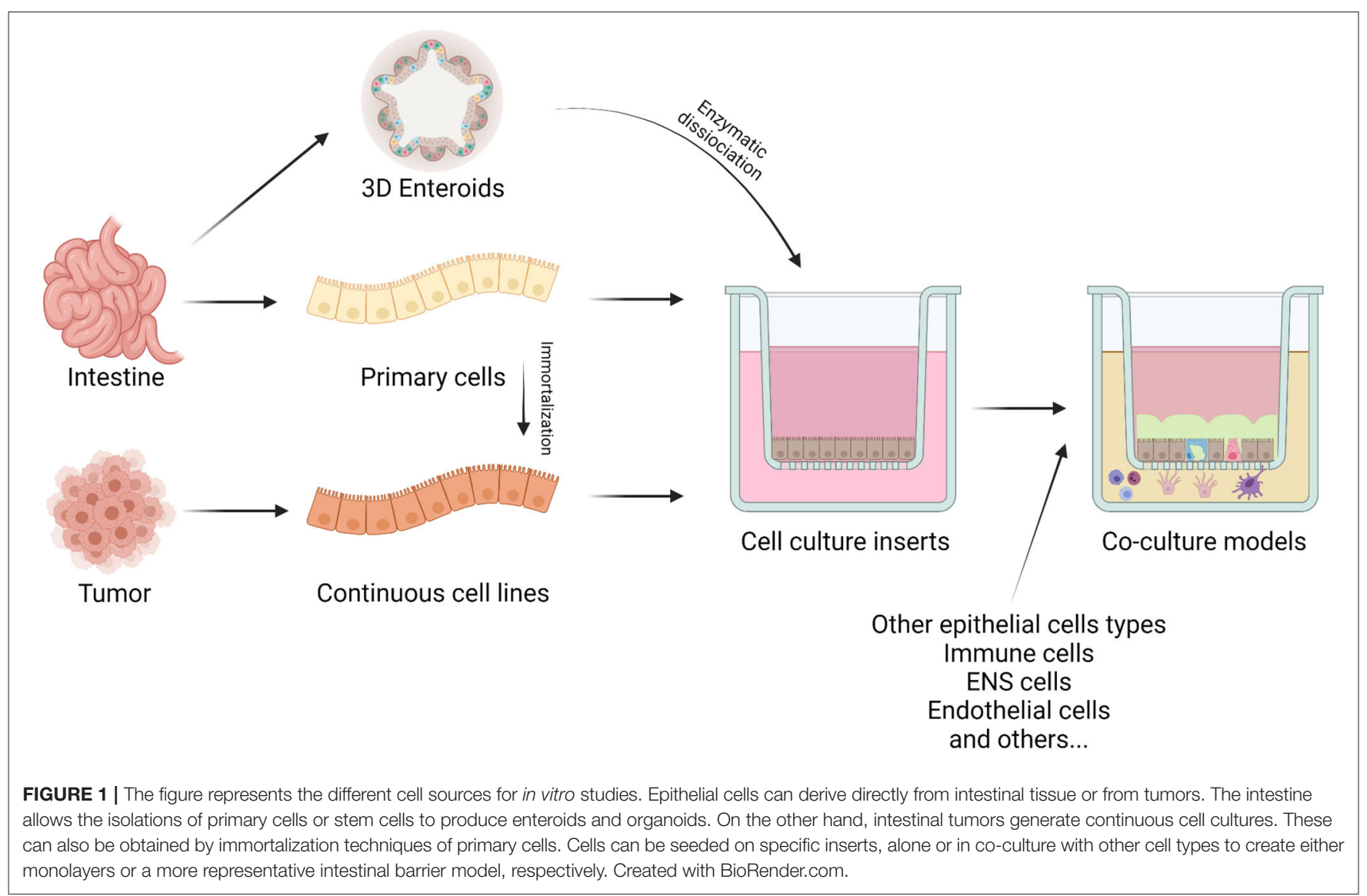

\section{Porcine: IPEC-1, IPEC-J2, PoCo83-3 and ZYM-SIEC02}

Two non-transformed cell lines, IPEC-1 and IPEC-J2, were established from 12-h-old piglets in 1989 (27, 28). These two cell lines have a different morphology: IPEC-1 has a cobblestone morphology, and IPEC-J2 has an elongated phenotype with a higher cell area (29). In contrast to Caco-2 cells, these cell lines cannot escape attachment-regulated apoptosis (called anoikis), which prevents uncontrolled proliferation (30). Nossol et al. (31) reported a significant upregulation of p53 and other differentiation pathways in IPEC-J2, which can explain the huge proliferative capacity of this not transformed nor tumorigenic cell line. These cell lines can grow and express a TJ network if cultured on permeable support (32). IPEC-J2 is the most commonly used cell line for in vitro studies concerning the effect of botanicals on the pig intestine (33-36).

In 2017 Kaiser et al. (37) established a new porcine colonic cell line PoCo83-3. Cells were isolated from the proximal colon of a 3-week-old piglet and transduced using a recombinant retroviral vector construct containing the simian virus 40 large $\mathrm{T}$ antigen. PoCo83-3 showed epithelial cell-specific features, and the expression of keratin 18, E-cadherin, and the tight junctionassociated proteins. To validate PoCo83-3 as an in vitro model in epithelial barrier research, proinflammatory cytokine-inducible alterations in barrier integrity were demonstrated by incubating the cells with TNF- $\alpha$ and IFN- $\gamma$ for $48 \mathrm{~h}$.
In 2014, Wang et al. established a porcine intestinal epithelial cell line (ZYM-SIEC02) by introducing the human telomerase reverse transcriptase gene into small intestinal epithelial cells derived from a neonatal, 1-day old piglet. ZYM-SIEC02 retained the morphological and functional characteristics typical of primary swine intestinal epithelial cells (38). Recently, these cells have been used to study the protective effect and mechanism of carnosol on pig intestinal oxidative stress (39).

\section{Bovine: BIEC and FBCEC}

In 2000, Föllmann et al. isolated and established for the first time a bovine intestinal epithelial cell (BIEC) culture from the bovine colon (40). Then other research groups isolated established other BIEC cultures (41-45). Researchers have used BIEC to study some pathogenic challenges such as rotavirus infections (45), toxins (46), short-chain fatty acids, (47), or other pathogens (41, 48-51). In 2019 Katwal et al., immortalized for the first time BIEC line using different methods (52). In particular, Katwal et al. (53) isolated primary BIEC from ileal tissue fragments from a 2-day old dairy calf. Then they purified the cultures from fibroblasts using a limiting dilution method and then immortalized them using SV40 large T-antigen, hTERT, or HPV E6 proteins. These cells have been used to test their susceptibility to enteric pathogens, and TLR mediated immune responses.

Moreover, Kaushik et al. (45) isolated fetal bovine colon epithelial cells (FBCECs) for the first time. They isolated 
the epithelial cells from two 110-130-day-old fetuses, then the cultured cells were evaluated for susceptibility to enteric viral infection. Immunohistochemical staining for cytokeratin confirmed that $60-75 \%$ of cultured cells were epithelial cells. Furthermore, following infection with bovine rotavirus (BRV) over $80 \%$ of cells in the ileal and jejunal cultures contained viral protein at $16 \mathrm{~h}$ post-infection. Kuroda et al. (54) successfully immortalized these cells in 2015 and found that these cells are also susceptible to Salmonella infections.

\section{Poultry: Primary Cells}

For poultry, where immortalized cells are not available, several research groups have tried to isolate primary intestinal epithelial cells. Immerseel et al. (55) created, for the first time, a primary chicken colonocyte culture able to be infected by $S$. enteritidis, starting from adult chickens. Dimier-Poisson et al. (56) created a chicken intestinal epithelial cells (cIECs) culture able to be infected by E. tenella and positive for E-cadherin and cytokeratin on flow cytometry analysis, starting from chicken 18-day-old embryos. Later, Yuan et al. (57) isolated cIECs starting from 14-day-old embryos using the enzyme collagenase type I to recover intestinal aggregates able to generate a monolayer that survived until $9 \mathrm{~d}$ in culture; however, cell characterization was missing. Both Kaiser et al. (58) and, more recently, Bai et al. (59), isolated cIECs with a proper morphology, but they degenerated after 7-10 d in culture without reaching confluence. Kaiser et al. also compared monolayers isolated from embryonic and adult intestines, demonstrating no difference in growth. Despite that, the excessive mucus production of adult tissues makes them less suitable than embryonic tissues for cIECs isolation (58). Moreover, Bar Shira and Friedman (60) isolated cIECs starting from 17-day-old embryos and obtained a culture positive for villin and E-cadherin. They showed that these cells could take up and process bacteria and respond to bacterial products (LPS and LTA), and they express proinflammatory cytokine genes (interleukins 6 and 18) and the acute-phase proteins avidin, lysozyme, and the secretory component derived from the polymeric immunoglobulin receptor. Rath et al. (61) proved that it is also possible to create a chicken intestinal epithelial cell line from the intestinal tissues of adult chickens and to maintain these cells through 6-7 passages. However, these cells lack proper epithelial morphology since IF characterization showed that Zonula occludens-1 (ZO1) was not located in their intercellular junctions, a typical trait of intestinal enterocytes. Recently, Ghiselli et al. (62) developed a protocol that required various growth factors to culture cIECs. They showed that it is possible to maintain these cells for up to 14 days in culture. These cells showed proper morphology and TJs localization. They characterized the cIECs for various intestinal markers, such as ZO1, cytokeratin 18, and E-cadherin, and cultured them on a permeable support. Unfortunately, creating a reproducible protocol to create an in vitro model with primary cells isolated from fresh intestinal tissue remains a challenge (63). Organoid technology has changed the research landscape, focusing the efforts of research teams on creating models that can closely represent the in vivo situation (64).

\section{Enteroids From Production Animals}

Barker et al. (65) identified, for the first time, intestinal stem cells (Lgr5+) in small intestinal and colonic crypts. These cells can differentiate into all intestinal epithelial cells, and they can be cultured in vitro for long periods, forming "mini guts" or spherical $3 \mathrm{D}$ organoids $(66,67)$. 3D organoids are useful tools to study epithelial cell differentiation, function, and hostpathogen interactions. Unfortunately, they are heterogeneous in terms of viability, their shape limits bioactive compound penetration, and they are usually unsuitable for food supplement screening and permeability studies (68-70). To overcome this issue, organoid-derived monolayers were developed. Organoidderived monolayers (or enteroid monolayers) are 2D cultures derived from Lgr5+ stem cells (71), and they were obtained by digesting $3 \mathrm{D}$ organoids or seeding isolated intestinal crypts. Enteroid monolayers can be cultured on permeable supports, and they can reproduce all of the different epithelial cells present in the in vivo intestinal tissue (72). The idea is to seed dissociated cells obtained from organoids or crypts on Transwell ${ }^{\circledR}$ inserts coated with extracellular matrix proteins (i.e., collagen). Here cells produce a tight 2D monolayer and epithelial differentiation can be induced by removing niche staminal factors or by using an air-liquid interface, as shown for pig enteroids (73). Hee et al. (74) created a porcine enteroid monolayer cultured on Transwell $\AA$ filters by enzymatically dissociating a 3D organoid. This enteroid monolayer can form a TJ network with high transepithelial electrical resistance (TEER) in 3 days, thus representing a robust platform for exploring intestinal health and permeability and bioactive compound testing in swine (74). In 2019, Töpfer et al. created a bovine colonoid from colonic organoids creating a monolayer with a TEER value of $324 \Omega^{*} \mathrm{~cm}^{2}$ (75). Recently, Resende et al. (76) utilized the same approach using a porcine enteroid monolayer to study the effects of Lawsonia intracellularis infection. For other production animals, enteroid monolayers have not yet been developed. Organoids and enteroids can be considered the most accurate tool to study gut health and, in the future, they will be largely used as the golden standard model.

\section{IN VITRO CO-CULTURE MODELS}

An ideal in vitro model must resemble the key characteristics of the intestinal epithelium (13). Epithelial cells seeded on permeable supports can be cocultured with other cell types to mimic a more realistic response to different apical stimuli (77). HT29 is another human colorectal adenocarcinoma cell line that was isolated in 1964 (78). This cell line contains mucusproducing goblet cells. In particular, they can express both secretory (MUC2, MUC5AC, MUC6) and membrane-bound (MUC1, MUC3, MUC4) mucin types (79). HT29-derived cell lines (HT29-MTX) cocultured with Caco-2 cells are a valuable tool to study mucin activity and mucus effects on interactions with botanicals, pathogens, or microflora (15). Arranz et al. (80) tested the absorption across the intestinal epithelium (through Transwell $\AA$ permeable support) of encapsulated rosemary extract on both Caco-2 and Caco-2/HT29-MTX cocultures. They 
TABLE 1 | In vitro and ex vivo model benefits and limitations.

\begin{tabular}{|c|c|c|}
\hline Model & Benefits & Limitations \\
\hline Caco-2 (in vitro) & $\begin{array}{l}\text { - Can be polarized } \\
\text { - Cost-effective } \\
\text { - Easy to use } \\
\text { - Extensive literature available } \\
\text { - Commercially available }\end{array}$ & $\begin{array}{l}\text { - Cancerous origin } \\
\text { - Long times to differentiate } \\
\text { - Genetic drift }\end{array}$ \\
\hline IPEC-J2-IPEC-1 (in vitro) & $\begin{array}{l}\text { - Can be polarized } \\
\text { - Commercially available } \\
\text { - Good for studying the small intestine } \\
\text { - Non-cancerous origin }\end{array}$ & - Not a suitable model for the colon \\
\hline BIEC and FBCEC (in vitro) & $\begin{array}{l}\text { - Good for studying bovine pathogens } \\
\text { - Non-cancerous origin }\end{array}$ & $\begin{array}{l}\text { - Not commercially available } \\
\text { - Few papers available } \\
\text { - Uncertain polarization capacity }\end{array}$ \\
\hline Primary intestinal epithelial cell lines (in vitro) & $\begin{array}{l}\text { - Can be polarized } \\
\text { - Contain multiple cell types } \\
\text { - Closer to an in vivo situation } \\
\text { - Non-cancerous origin Physiologic relevance }\end{array}$ & $\begin{array}{l}\text { - Not commercially available } \\
\text { - Expensive maintenance } \\
\text { - Short lifetime (weeks) } \\
\text { - Needs to sacrifice animals to start a new culture }\end{array}$ \\
\hline Organoids/enteroids (in vitro) & $\begin{array}{l}\text { - Can be grown 2D or 3D } \\
\text { - Can be polarized } \\
\text { - Contain all epithelial cell types } \\
\text { - Closer to an in vivo situation } \\
\text { - Non-cancerous origin Physiologic relevance }\end{array}$ & $\begin{array}{l}\text { - Not commercially available } \\
\text { - Very expensive maintenance } \\
\text { - Difficult to obtain and manage } \\
\text { - Short lifetime (weeks) } \\
\text { - Needs to sacrifice animals to start a new culture }\end{array}$ \\
\hline Ussing chamber (ex-vivo) & $\begin{array}{l}\text { - Tissue is polarized } \\
\text { - Can obtain barrier function and transport data } \\
\text { - Contain all epithelial cell types } \\
\text { - Physiologic relevance }\end{array}$ & $\begin{array}{l}\text { - Short lifetime }(<5 \mathrm{~h}) \\
\text { - Require expensive equipment and knowledge } \\
\text { - Needs to sacrifice animals }\end{array}$ \\
\hline Everted intestinal ring & $\begin{array}{l}\text { - Absence of maintenance } \\
\text { - Closest to in-vivo situation } \\
\text { - Contain all epithelial cell types }\end{array}$ & $\begin{array}{l}\text { - Short lifetime }(<3 \mathrm{~h}) \\
\text { - Needs to sacrifice animals } \\
\text { - Muscularis mucosa and lamina propria presence }\end{array}$ \\
\hline InTESTine ${ }^{T M}$ & $\begin{array}{l}\text { - Tissue is polarized } \\
\text { - Can obtain barrier function and transport data } \\
\text { - Physiologic relevance } \\
\text { - Contain all epithelial cell types } \\
\text { - Cheaper than Ussing chamber }\end{array}$ & $\begin{array}{l}\text { - Short lifetime } \\
\text { - Needs to sacrifice animals }\end{array}$ \\
\hline
\end{tabular}

found that when cocultures were employed, the presence of mucus caused higher retention in the apical layer compared to the Caco-2 monolayer. Volstatova et al. (81) used a Caco2/HT29-MTX coculture to study the effect of antioxidant compounds (apple, tea, and coffee polyphenols) on mucin expression. The results showed that each polyphenol compound induces different expression patterns of mucin genes. Schimpel et al. (82) found that the best ratio of Caco-2 cells to HT29MTX cells was 70:30. This ratio granted permeability results near those obtained from ex vivo permeability assays using porcine intestinal mucosa. In this study, Schimpel and colleagues replicated a triple-coculture model developed in 2013 by Antunes et al. This model consists of a triple co-culture of Caco- 2 cells with Raji B cells and HT2-MTX (83). Raji B is a cell line that originated from a human Burkitt's lymphoma that, if cultured on the basolateral side of a permeable membrane, can induce an $\mathrm{M}$ cell phenotype in Caco-2 cells cultured on the apical side (8284). Another important intestinal barrier function is the immune response. Culturing Caco-2 cells or, more generally, epithelial cells on the apical side of permeable support allows coculture of basolateral side immune cells. This coculture can mimic the immune response to a challenge (85). Cocultivation of Caco-2 cells with monocyte-derived dendritic cells (85), Raji B cells
(M-cells) (82), or THP-1 cells (macrophages) (86) allows us to study communication between immune cells and epithelial cells. The ENS is another important player in intestinal physiology. In 2001, Satsu et al. showed that coculturing Caco- 2 cells with PC12 cells (a neural cell line derived from a pheochromocytoma) can reproduce the interactions between the enteric nervous system and epithelial cells (87). Finally, it is possible to coculture all of the previous models with probiotics, pathogens, and other bacteria to study the interaction between the intestinal barrier and the microflora (88).

\section{EX VIVO MODELS}

Ex vivo models are living functional tissues or organs cultivated in an artificial environment outside the organism (89). Table 1 reports a summary of the benefits and limitations of different in vitro and ex vivo models. Figure 2 illustrates the different ex vivo models.

\section{Ussing Chamber}

Ussing and Zerahn (90) developed the Ussing chamber to study transepithelial ion transport across frog skin. Later, Grass and Sweetana (91) adapted it to test the intestinal permeability of 

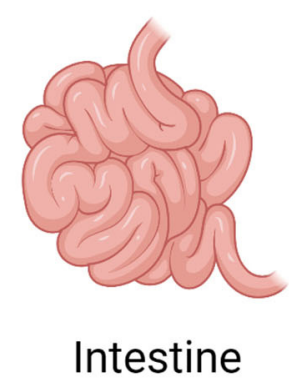

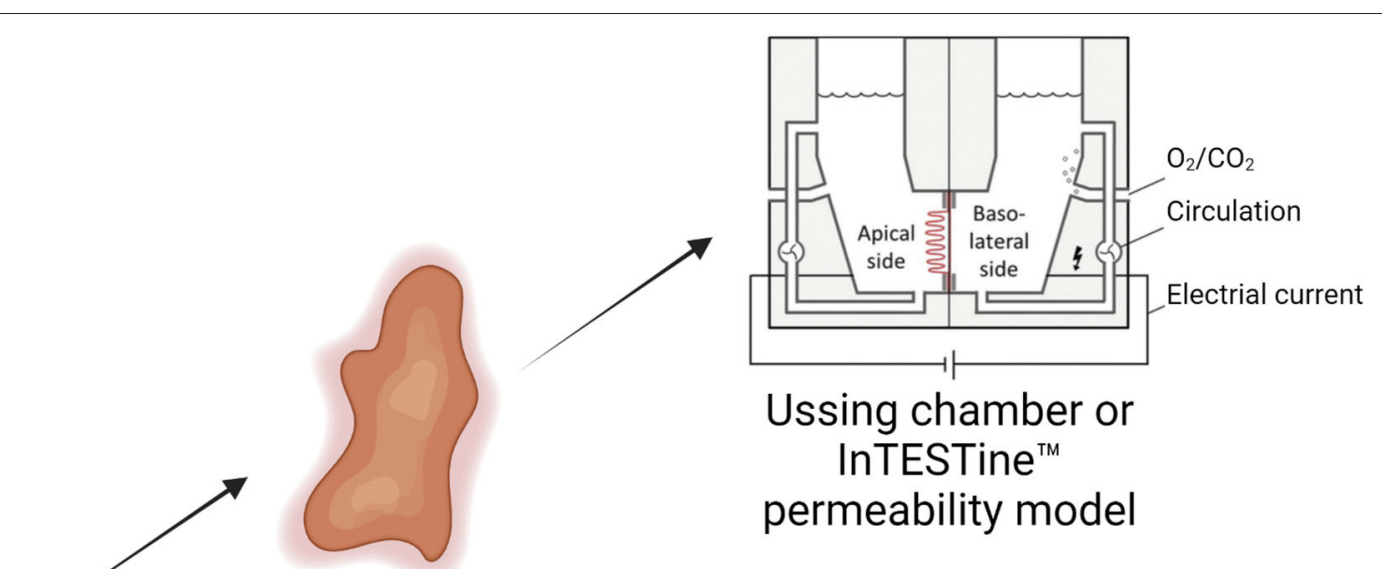

Mucosal tissue fragment

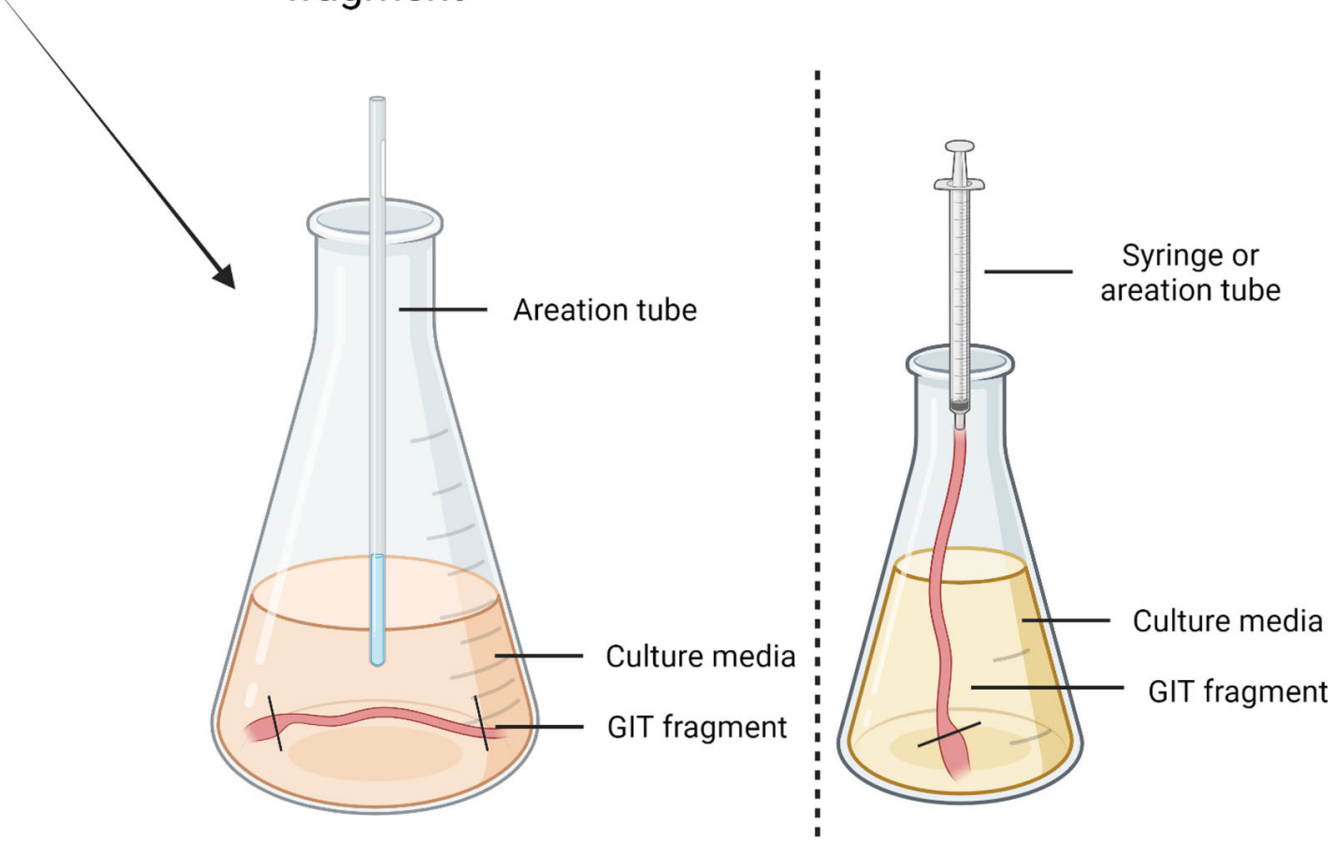

\section{Everted intestinal model}

FIGURE 2 | The figure represents the different ex vivo models. The Using chamber or the inTESTine ${ }^{\text {TM }}$ system works by removing a segment of intestinal mucosa from an animal, which is then mounted between two halves of a chamber filled with physiological buffer to simulate the mucosal and basolateral passage flow. In everted intestinal rings, the animal's intestine is cut into ring slices and transferred into oxygenated culture media. This model is a useful tool for investigating uptake into intestinal cells and metabolism in different regions of the intestine-Created with BioRender.com.

drugs. The Ussing chamber works by removing a segment of intestinal mucosa from an animal, opening it to form a flat sheet between two halves of a chamber filled with physiological buffer $\left(95 \% \mathrm{O}_{2}, 5 \% \mathrm{CO}_{2}, 37^{\circ} \mathrm{C}\right)(92,93)$. Then, by applying a current, it is possible to measure some electrical values that can be indicators of intestinal health (94). Using a fluorescent tracer (such as FD4 or lucifer yellow), it is also possible to measure the para-cellular flux (92). The Ussing chamber is the most commonly used ex vivo system for production animals and it has been used for many applications: to test the effect of botanicals and organic acids (95), to evaluate alternatives to in-feed antibiotics (96), to determine the impact of microbes and probiotics on intestinal ion transport (97), and to study transepithelial transport and intestinal permeability (92). Table 2 reports typical TEER values of the different intestinal tracts.

\section{Everted Intestinal Ring}

In everted intestinal rings, the animal's intestine is cut into ring slices (30-50 mg, 2-5 mm width) and put into oxygenated media $(102,103)$. This model is a useful tool for investigating uptake 
TABLE 2 | TEER values for different cell lines, cocultures, and intestinal tracts.

\begin{tabular}{|c|c|c|c|}
\hline Cell or Tissue & TEER $\left(\Omega^{*} \mathrm{~cm}^{2}\right)$ & $\begin{array}{l}\text { Equipment } \\
\text { used }\end{array}$ & Reference \\
\hline Small Intestine (ex-vivo) & $50-100$ & Ussing chamber & (98) \\
\hline Colon (ex-vivo) & $300-400$ & Ussing chamber & (98) \\
\hline Caco-2 & $1,100-1,350$ & $\begin{array}{l}\text { Millicell-ERS } \\
\text { system }\end{array}$ & (99) \\
\hline Caco-2/HT29-MTX & $100-300$ & $\begin{array}{l}\text { Millicell-ERS } \\
\text { system }\end{array}$ & $(100)$ \\
\hline Caco-2/Raji B & $80-100$ & $\begin{array}{l}\text { Millicell-ERS } \\
\text { system }\end{array}$ & $(101)$ \\
\hline Caco-2/HT29-MTX/Raji B & $50-70$ & $\begin{array}{l}\text { Millicell-ERS } \\
\text { system }\end{array}$ & (101) \\
\hline Caco-2/THP-1 & $80-100$ & $\begin{array}{l}\text { Millicell-ERS } \\
\text { system }\end{array}$ & (86) \\
\hline Caco-2/PC12 & $80-100$ & $\begin{array}{l}\text { Millicell-ERS } \\
\text { system }\end{array}$ & (87) \\
\hline IPEC-J2 & $7,000-8,000$ & $\begin{array}{l}\text { Millicell-TERS- } \\
\text { electrode }\end{array}$ & (31) \\
\hline IPEC-1 & $6,000-7,000$ & $\begin{array}{l}\text { Millicell-TERS- } \\
\text { electrode }\end{array}$ & (31) \\
\hline PoCo83-3 & $4,000-6,000$ & $\begin{array}{l}\text { EVOMX } \\
\text { ohmmeter }\end{array}$ & (37) \\
\hline Bovine colonoid monolayer & $300-400$ & $\begin{array}{l}\text { Chopstick- } \\
\text { electrode } \\
\text { epithelial } \\
\text { voltohmmeter } \\
\text { EVOM2 }\end{array}$ & (75) \\
\hline Porcine enteroid monolayer & $1,000-1,150$ & cellZscope® & (74) \\
\hline Primary clECs & $50-70$ & $\begin{array}{l}\text { Millicell-ERS } \\
\text { system }\end{array}$ & (62) \\
\hline
\end{tabular}

into intestinal cells and metabolism in different regions of the intestine (104). The simplicity of this method, the absence of maintenance, and the closeness to an in vivo situation are the principal advantages of this method (103). A disadvantage of this approach is the presence of the muscularis mucosa, which is not usually removed. Therefore, this model does not reflect the actual intestinal barrier, because compounds under investigation pass from the lumen into the lamina propria. Unfortunately, only a few papers written in the 1960s are available regarding the use of everted intestinal rings in production animals $(105,106)$.

\section{InTESTine ${ }^{\mathrm{TM}}$ Permeability Model}

Voortman and colleagues in 2012 described a high-throughput system using in vitro intestinal segments from pigs (107). The tissue was incubated in a 24-well culture plate to study the effects of fatty acids on the release of gastrointestinal hormones in pigs (107). This model has been adjusted and commercialized as InTESTine ${ }^{\mathrm{TM}}$, which uses porcine intestinal mucosal explants to investigate intestinal absorption $(108,109)$. This model allows us to test compounds directly on the intestinal epithelium and measure transport and/or secretion across the epithelial tissue. Moreover, this setup can be used in a humidified oxygenated incubator at $37^{\circ} \mathrm{C}$ on a rocker platform (109). This system has been used to study intestinal physiology (110), chemosensing (111), microbiota interactions (108), and intestinal stem cells (112).

\section{IN VITRO AND EX VIVO ASSAYS}

Intestinal permeability assays are commonly used as indicators of "gut barrier health" (113). Paracellular permeability and transepithelial electrical resistance, molecular approaches (i.e., qPCR or ELISA), and immunofluorescence assays (IF) are common ways to assess the intestinal barrier status in vitro and ex vivo.

\section{Tracers and Paracellular Permeability}

The paracellular permeability assay (PCP) consists of quantifying the passage of a tracer molecule through the paracellular route, typically used by medium-sized hydrophilic molecules $(\leq 600 \mathrm{Da}$ in vivo; $\leq 10 \mathrm{kDa}$ in vitro in cell lines) from the luminal side to the basolateral side of the intestinal epithelium (114). PCP can be performed both in vitro (culturing cells on a permeable system) or ex vivo. In the 1990s, a paracellular permeability assay on human jejunal segments was performed with the Ussing chamber for the first time (115). Hubatsch et al. (116) explained how to perform a permeability assay on Caco- 2 cells cultured on filters. This protocol can be shifted and readapted for every intestinal epithelial cell line that can grow on permeable supports. During PCP, tracers are monitored using a fluorescent dye (e.g., fluorescein isothiocyanate) bonded typically to a sugar (e.g., mannitol or dextran) that can pass through the epithelium only using the paracellular method (16). Tracer molecules are also commonly used in vivo. They are non-digestible sugars such as labeled dextran (FITC-d), lactulose, 51Cr-EDTA, mannitol, or PEG (117) which can be later quantified in urine or blood. These methods are widely used for example in poultry [recently well described by Liu et al. (118)] but the output in most of these techniques is a single value of permeability, which does not allow to distinguish which region of the gut is affected, and therefore must be used in combination with other methods (117). These molecules can be used in ex vivo explants (i.e., Ussing chamber) allowing evaluation of very specific regions of the GI tract. However, tissue viability is a big concern, and therefore incubation times no longer than $3 \mathrm{~h}$ are recommended (119). Dextran is a non-digestible sugar $(>1 \mathrm{kDa})$, and it represents a typical agent that is transported via the paracellular route $(120$, 121). Transcytosis of dextran has never been reported. However, dextran pinocytosis was observed, but it is a very slow process and could be ignored compared to its paracellular transport (122). The PCP is measured as a ratio between the fluorescence read on the apical side and the fluorescence read on the basolateral side (123). Before starting an experiment, a standard curve was generated to relate the tracer molecule concentration to the fluorescence emission (124). A healthy epithelium will retain most of the tracer molecule in the apical part, while a damaged epithelium will leave the tracer free to move to the basolateral part. For example, during a challenge, it is important to perform PCP using tracers with different molecular weights to reveal the size selectivity of TJs and to see if this has been compromised (125). Van Itallie et al. (126) reported that modest permeability 
changes are more difficult to detect with large tracers $(>10 \mathrm{kDa})$ except in cases where the barrier is catastrophically damaged. Using smaller molecules $(<4 \mathrm{kDa})$, it is possible to detect less extreme barrier damage (127). PCP using dextran is used to determine the effect of botanicals $(34,95)$, oxidative stress (128), or inflammatory (129) challenges on the TJs network and, more generally, on animal intestinal health (130).

\section{Transepithelial Electrical Resistance and Short Circuit Current}

Transepithelial electrical resistance is a rapid, non-invasive method for quantifying barrier tissue integrity by measuring electrical resistance across the epithelium. TEER can be measured in both in vitro and ex vivo models. There are two principal ways to measure TEER: resistance-based measurements and impedance-based measurements (131). In vitro, resistance-based measurements are performed by placing "stick electrodes" on the apical and basolateral sides of a cell layer grown on a semipermeable membrane and by applying an alternate current signal $(12.5 \mathrm{~Hz}$ and $10 \mu \mathrm{A})$. Ex vivo (i.e., an Ussing chamber), the potential difference across the epithelial tissue can be determined using $\mathrm{Ag} / \mathrm{AgCl}$ electrodes. Then, the TEER value is determined using Ohm's law: measuring both current and voltage across the cell layer or the potential difference across the epithelial tissue. Resistance is given by the combination of the transcellular and paracellular pathways. Different factors, such as medium resistance, electrode-medium interfacial resistance, and the resistance of the semipermeable membrane (in in vitro assays), contribute to the TEER. A simple approach to reduce these variables is to subtract from all resistance measurements the resistance of an identical testing configuration without the cell layer (a blank) (131). Impedance-based measurement is a more advanced technique that can allow for the determination of TEER in a more robust manner (131). Measurements are taken across a range of current frequencies, and the resulting impedance (resistance in an alternate current circuit) is plotted as a function of frequency. The resulting total impedance value provides information not only about the TEER but also about the capacitance (ratio of the change in electric charge over the corresponding change in electric potential) of the cell layer or tissue, which can be a readout parameter (132). The software can automatically determine the best-fit parameters and extract the TEER using standardized cell support models (132). Table 2 reports the typical TEER values of the cell lines and intestinal tracts.

Another important parameter is the short circuit current (ISC). ISC is measured in ex vivo assays using the Ussing chamber (92). When performing the assay, it is possible to use, in one of the two halves, a buffer without specific ions (i.e., $\mathrm{Na}^{+}$or $\mathrm{Ca}^{2+}$ ). Naturally, the epithelium, using ion pumps, balances the ion concentration between the two sides, generating a potential difference. Applying a certain external current, the ISC, it is possible to nullify this potential difference, creating a "short circuit" (92). ISC, as well as TEER, is influenced by the epithelial barrier status: a healthy epithelium will have a higher ISC than a disrupted epithelium (90).

\section{Immunofluorescence Assays}

To visualize the health status of the epithelium in vitro, it is also possible to use immunofluorescence (IF) or molecular approaches. IF allows us to take a picture of the health condition of the examined epithelium during a challenge or treatment. Kawauchiyaa et al. (133), in their research article, showed a correlation between the decrease in TEER values and ZO1 degradation by IF. Treating a Caco- 2 cell culture with patulin, an antibiotic molecule, caused a significant decrease in TEER values and a complete disappearance of $\mathrm{ZO} 1$ in the IF assay (133). Van Itallie et al. (126) demonstrated the same results in MDCK cells. The absence of ZO1 expression in knockout cells (as observed by IF) was correlated with a higher PCP and a loss of normal epithelial cell morphology. Moreover, other molecular assays, such as qPCR or ELISA, are available and cost-effective alternatives to investigate the effect of botanicals on protein or cytokine expression (134).

\section{Different TJs, Different Assay}

PCP and TEER are two of the most commonly used assays to investigate the barrier function of an intestinal model in vitro or ex vivo. Different TJs proteins influence TEER and PCP assays (135). Claudin-based pores $(136,137)$ and occludin (138) influence the TEER, which measures the ion flux through the epithelium. Alternatively, PCP measures the flux of larger molecules via a route called the "leaky pathway" (1, 126, 139), which is principally affected by ZO1 expression. Suzuki et al. (138) treated Caco-2 cells with kaempferol, a flavonoid found in kale, beans, tea, spinach, and broccoli (140). This treatment increased claudin-3 and occludin expression in IF. Consequently, the TEER values increased, but PCP was not affected (138). Endo et al. (141) also confirmed the correlation between decreased claudin expression and decreased TEER values. Van Itallie et al. (126) demonstrated that the absence of ZO1 expression observed by IF (in MDCK knockout cells) was correlated with a higher PCP and a loss of normal epithelial cell morphology, but the TEER values were not affected. Last, Mani et al. (142) reported a correlation between increased TEER and increased expression of claudin-3 and claudin- 4 after treating heat-stressed IPEC-J2 cells with zinc butyrate.

\section{DISCUSSION}

In this review, a descriptive analysis of in vitro and ex vivo models available to study animal intestinal permeability and health was performed.

First of all, an essential discussion point concerning in vitro models is the origin of the cell culture. Caco- 2 cells are the "gold standard" cellular model for in vitro intestinal barrier assays, even for animals (16). But these cells are derived from a human colorectal carcinoma (17). These cells are cheap, easy to use, and maintain. Caco-2 cells are easy to culture and they can differentiate into mature enterocytes spontaneously when reaching confluence. The origin of these cells is a crucial limitation because some pathogens and some pathways or microbial interaction could be not so close to reality due to their origin. This limitation is also applicable to other human cell lines 
used in animal studies i.e., HT29 used in co-culture models. In this context, some continuous cell lines derived from pigs and bovines have been established. Their non-cancerous origin is the major benefit of these cell lines, and they better represent a pig or bovine small-intestinal epithelium. Moreover, immortalized cell lines are considered the most cost-effective tool because they can be passaged indefinitely, but due to the different culture conditions and different numbers of passages among different laboratories, immortalized cells could often acquire different properties overtime. Thus, the expression of different markers on the enterocytes, can change with increasing numbers of passages. Also, parameters like TEER and proliferation rate have been reported to increase with passage number (143). Primary cells are often considered to be more biologically and physiologically similar to in vivo situations. But they are more expensive to maintain, and they have a limited lifespan, requiring frequent isolation from live tissue.

Another interesting discussion point is the epithelial composition. The normal intestinal epithelium is made up of several cell types and differences in gene expression profiles are not only observed in the mucosal epithelium along the GIT but also along the crypt-villus axis. Experiments done with monotype-monolayers cannot be directly compared with the in vivo situation. However, they can be an ideal way to study molecular mechanisms in a simplified environment. Lastly, the absence of a mucus layer above the cells could be another limitation in the study of enterocytes/microbial interactions that can affect intestinal permeability and health. To overcome these problems many efforts have been made to create enteroid monolayers, 3D organoids, and more complex systems for production animals (144), despite the high cost and particular medium or support necessary to culture them. The $2 \mathrm{D}$ enteroid and $3 \mathrm{D}$ organoids could be a valid alternative to have a closer cellular composition to the in vivo situation. Moreover, specific differentiation methods have allowed researchers to examine celltype-specific responses and properties including barrier function, and would be useful tools to examine host-microbe interactions.

As previously described, it is better to use primary cells or organoids, preferably derived from the animal of interest, as they carry specific properties of the animal species they derive from. Ex vivo systems can add complexity and functional crosstalk between cell types that are not present in in vitro systems (143). The InTESTine ${ }^{\mathrm{TM}}$ system contains a mucus layer that enables it to be more successfully utilized in conjunction with single or mixed communities of bacteria. Unfortunately, thus model been validated for this specific purpose yet.

The Ussing chamber is widely used for these assays. It uses live intestinal mucosal tissue that can be treated before or during the assay, and multiple parameters can be measured. The Ussing chamber can be also a valid system to study the intestine/microbiota interaction. For example, it has been used to study bacterial translocation into colonic mucosa (145). In another study, Clostridium difficile was tested in a Ussing chamber to study the interactions with host epithelial cells and the bacterial and toxin-mediated cellular events (146). However, the short tissue viability is the major disadvantage of this system, which cannot be used for longer-term studies $(>5 \mathrm{~h})$. Nevertheless, the ex vivo models do not permit a more sequential and basic approach provided by the other in vitro assays. Thus, they must be seen as a complement and not as an alternative to in vitro studies. Furthermore, they can be more difficult to implement.

In comparison to intestinal epithelial cell lines, intestinal organoids and 2D enteroids contain all the different specialized cell types of the intestinal epithelium. Thus, intestinal organoids represent a promising tool for studies on specific regions of the intestine. Seeger in 2020 widely discussed the usage of organoids derived from farm animals (147). For certain studies (i.e., bioactive molecule testing) the use of standardizable monolayers is more appropriate than the use of organoids. In humans, it is also possible to generate intestinal organoids and derived monolayers from human pluripotent stem cells (148). Actually, no published studies exist on the generation of intestinal organoids differentiated from pluripotent stem cells of farm animal species. In 2021 Kumar et al. (149) well discussed the current achievements in the derivation of pluripotent stem cells from farm animals, and discuss the potential application areas. Another interesting perspective is the usage of 3D scaffolds. A first attempt was made by Sala et al. (144). Jejunal crypts of pigs were engrafted intraperitoneally on biodegradable scaffold tubes and examined for the cell types present after seven weeks (144). The resulting organoids had a columnar epithelium expressing enterocytes, goblet cells, and intestinal stem cells. They were surrounded by intestinal subepithelial myofibroblasts, representing the lamina propria and smooth muscle cells with some neuronal cells among them, representing a lamina muscularis layer. These advanced in vitro models are not as complex as the in vivo situation, but they allow the investigation of interactions between the surrounding cell types and the intestinal epithelium in a more complete manner.

\section{CONCLUSION}

All of the models and techniques illustrated in this review could be useful for investigating and better understanding the interactions among the different intestinal components. Moreover, in vitro or ex vivo models are needed to elucidate the mechanistic foundations and physiological significance of beneficial or pathogenic relationships between the GIT epithelial barrier and the external environment (9), creating wellcontrolled and repeatable conditions. A healthy intestinal barrier allows the maintenance of mucosal immune homeostasis and prevents the onset of uncontrolled inflammation. The usage of in vitro or ex vivo models could be an optimal way to study strategies to improve the gut barrier in compliance with the $3 \mathrm{Rs}$ approach.

\section{AUTHOR CONTRIBUTIONS}

FG, BR, AP, and EG equally contributed to the conception and creation of the review. All authors read and approved the final manuscript. 


\section{REFERENCES}

1. Turner JR. Intestinal mucosal barrier function in health and disease. Nat Rev Immunol. (2009) 9:799-809. doi: 10.1038/nri2653

2. Kogut MH, Arsenault RJ. Editorial: gut health: the new paradigm in food animal production. Front Vet Sci. (2016) 3:71. doi: 10.3389/fvets.2016.00071

3. Pastorelli L, De Salvo C, Mercado JR, Vecchi M, Pizarro TT. Central role of the gut epithelial barrier in the pathogenesis of chronic intestinal inflammation: lessons learned from animal models and human genetics. Front Immunol. (2013) 4:28. doi: 10.3389/fimmu.2013.00280

4. Clarke G, Stilling RM, Kennedy PJ, Stanton C, Cryan JF, Dinan TG. Minireview: gut microbiota: the neglected endocrine organ. Mol Endocrinol Baltim Md. (2014) 28:1221-38. doi: 10.1210/me.2014-1108

5. Smirnova MG, Guo L, Birchall JP, Pearson JP, LPS. up-Regulates mucin and cytokine mrna expression and stimulates mucin and cytokine secretion in goblet cells. Cell Immunol. (2003) 221:42-9. doi: 10.1016/S0008-8749(03)00059-5

6. Doe WF. The intestinal immune system. Gut. (1989) 30:1679-85. doi: $10.1136 /$ gut.30.12.1679

7. Mowat AM. anatomical basis of tolerance and immunity to intestinal antigens. Nat Rev Immunol. (2003) 3:331-41. doi: 10.1038/nri1057

8. Zhu Y, Shi X, Lin X, Ye K, Xu X, Li C, et al. Beef, chicken, and soy proteins in diets induce different gut microbiota and metabolites in rats. Front Microbiol. (2017) 8:1395. doi: 10.3389/fmicb.2017.01395

9. Wu J, Ma N, Johnston LJ, Ma X. Dietary nutrients mediate intestinal host defense peptide expression. Adv Nutr. (2020) 11:92-102. doi: 10.1093/advances/nmz057

10. Festing S, Wilkinson R. The ethics of animal research. talking point on the use of animals in scientific research. EMBO Rep. (2007) 8:526-30. doi: 10.1038/sj.embor.7400993

11. Russell WMS, Burch RL. The Principles of Humane Experimental Technique. Methuen. (1959).

12. Shi D, Mi G, Wang M, Webster TJ. In vitro and ex vivo systems at the forefront of infection modeling and drug discovery. Biomaterials. (2019) 198:228-49. doi: 10.1016/j.biomaterials.2018.10.030

13. Costa J, Ahluwalia A. Advances and current challenges in intestinal in vitro model engineering: a digest. Front Bioeng Biotechnol. (2019) 7:144. doi: 10.3389/fbioe.2019.00144

14. Camilleri M, Madsen K, Spiller R, Van Meerveld B, Verne GN. Intestinal barrier function in health and gastrointestinal disease. Neurogastroenterol Motil Off J Eur Gastrointest Motil Soc. (2012) 24:503-12. doi: 10.1111/j.1365-2982.2012.01921.x

15. Pereira C, Costa J, Sarmento B, Araújo F. "Cell-Based in vitro Models for Intestinal Permeability Studies," in Concepts and Models for Drug Permeability Studies (Elsevier), 57-81. (2002).

16. Yeste J, Illa X, Alvarez M, Villa R. Engineering and monitoring cellular barrier models. J Biol Eng. (2018) 12:5. doi: 10.1186/s13036-018-0108-5

17. Sambuy Y, Angelis ID, Ranaldi G, Scarino ML, Stammati A, Zucco F. The Caco-2 cell line as a model of the intestinal barrier: In£Uence of Cell and culture-related factors on Caco-2 cell functional characteristics. 26. (2012)>

18. Fogh J, Orfeo T, Tiso J, Sharkey FE. Establishment of human colon carcinoma lines in nude mice. Pathobiology. (1979) 47:136-44. doi: 10.1159/000162930

19. Bishop W, Lin J, Wen J, E-cadherin mrna is differentially expressed during. CACO-2 cell differentiation: identification by differential display and analysis of promoter function: 10. J Pediatr Gastroenterol Nutr. (1997) 25:444. doi: 10.1097/00005176-199710000-00027

20. Natoli M, Leoni BD, D'Agnano I, Zucco F, Felsani A. Good Caco-2 cell culture practices. Toxicol In vitro. (2012) 26:1243-6. doi: $10.1016 /$ j.tiv.2012.03.009

21. Maubon N, Vee ML, Fossati L, Audry M, Ferrec EL, Bolze S, et al. Analysis of drug transporter expression in human intestinal caco2 cells by real-time PCR. Fundam Clin Pharmacol. (2007) 21:659-63. doi: 10.1111/j.1472-8206.2007.00550.x

22. Artursson P. Cell cultures as models for drug absorption across the intestinal mucosa. Crit Rev Ther Drug Carrier Syst. (1991) 8:305-30.

23. Chong S, Dando SA, Morrison RA. Evaluation of biocoat intestinal epithelium differentiation environment (3-day cultured Caco-2 cells) as an absorption screening model with improved productivity. Pharm Res. (1997) 14:1835-7. doi: 10.1023/A:1012112820371

24. Lentz KA, Hayashi J, Lucisano LJ, Polli JE. Development of a more rapid, reduced serum culture system for Caco-2 monolayers and application to the biopharmaceutics classification system. Int J Pharm. (2000) 200:41-51. doi: 10.1016/S0378-5173(00)00334-3

25. Cai Y, Xu C, Chen P, Hu J, Hu R, Huang M, et al. Development, validation, and application of a Novel 7-Day Caco-2 cell culture system. J Pharmacol Toxicol Methods. (2014) 70:175-81. doi: 10.1016/j.vascn.2014.07.001

26. Steube KG, Koelz A-L, Uphoff CC, Drexler HG, Kluess J, Steinberg P. The necessity of identity assessment of animal intestinal cell lines: a case report. Cytotechnology. (2012) 64:373-8. doi: 10.1007/s10616-011-9420-3

27. Gonzalez-Vallina R, Wang H, Zhan R, Berschneider HM, Lee RM, Davidson $\mathrm{NO}$, et al. Lipoprotein and apolipoprotein secretion by a newborn piglet intestinal cell line (IPEC-1). Am J Physiol-Gastrointest Liver Physiol. (1996) 271:G249-59. doi: 10.1152/ajpgi.1996.271.2.G249

28. Vergauwen H. “The IPEC-J2 Cell Line," In: K. Verhoeckx, P. Cotter, I. LópezExpósito, C. Kleiveland, T. Lea, A. Mackie, T. Requena, D. Swiatecka, H. Wichers editors The Impact of Food Bioactives on Health: In Vitro and ex Vivo Models, (Cham: Springer International Publishing), 125-134.

29. Nossol C, Diesing A-K, Walk N, Faber-Zuschratter H, Hartig R, Post A, et al. Air-Liquid Interface cultures enhance the oxygen supply and trigger the structural and functional differentiation of intestinal porcine epithelial cells (IPEC). Histochem Cell Biol. (2011) 136:103-15. doi: 10.1007/s00418-011-0826-y

30. Beauséjour M, Thibodeau S, Demers M-J, Bouchard V, Gauthier R, Beaulieu J-F, et al. Suppression of anoikis in human intestinal epithelial cells: differentiation state-selective roles of $\alpha 2 \beta 1, \alpha 3 \beta 1, \alpha 5 \beta 1$, and $\alpha 6 \beta 4$ Integrins. BMC Cell Biol. (2013) 14:53. doi: 10.1186/1471-2121-14-53

31. Nossol C, Barta-Böszörményi A, Kahlert S, Zuschratter W, FaberZuschratter H, Reinhardt $\mathrm{N}$, et al. Comparing Two intestinal porcine epithelial cell lines (IPECs): morphological differentiation, function and metabolism. PLoS ONE. (2015) 10:E0132323. doi: 10.1371/journal.pone. 0132323

32. Geens MM, Niewold TA. Optimizing culture conditions of a porcine epithelial cell line IPEC-J2 through a histological and physiological characterization. Cytotechnology. (2011) 63:415-23. doi: 10.1007/s10616-011-9362-9

33. Omonijo FA, Liu S, Hui Q, Zhang H, Lahaye L, Bodin J-C, et al. Thymol improves barrier function and attenuates inflammatory responses in porcine intestinal epithelial cells during lipopolysaccharide (LPS)-Induced Inflammation. J Agric Food Chem. (2019) 67:615-24. doi: 10.1021 acs.jafc. 8 b05480

34. Wu J, Yang C-L, Sha Y-K, Wu Y, Liu Z-Y, Yuan Z-H, et al. Koumine alleviates lipopolysaccharide-induced intestinal barrier dysfunction in IPEC-J2 cells by regulating Nrf2/NF- $\kappa$ B pathway. Am J Chin Med. (2020) 48:127-42. doi: 10.1142/S0192415X2050007X

35. Yuan Z, Liang Z, Yi J, Chen X, Li R, Wu Y, et al. Protective effect of koumine, an alkaloid from gelsemium sempervirens, on injury induced by $\mathrm{H} 2 \mathrm{O} 2$ in IPEC-J2 cells. Int J Mol Sci. (2019) 20:754. doi: 10.3390/ijms20030754

36. Zou Y, Wang J, Peng J, Wei H. Oregano Essential Oil Induces SOD1 and GSH Expression Through Nrf2 activation and alleviates hydrogen peroxideinduced oxidative damage in IPEC-J2 Cells. Oxid Med Cell Longev. (2016) 59:183. doi: 10.1155/2016/5987183

37. Kaiser B, Böttner M, Wedel T, Brunner RM, Goldammer T, Lesko S, et al. Establishment and characterization of an SV40 Large T antigen-transduced porcine colonic epithelial cell line. Cells Tissues Organs. (2017) 203:267-86. doi: $10.1159 / 000453394$

38. Wang J, Hu G, Lin Z, He L, Xu L, Zhang Y. Characteristic and functional analysis of a newly established porcine small intestinal epithelial cell Line. PLoS ONE. (2014) 9:110916. doi: 10.1371/journal.pone.0110916

39. Jiang Z, Li L, Hou L, Zhou Z, Wang C. Mechanism of protective effect of carnosol on pig intestinal epithelial cells. Int J Clin Exp Pathol. (2020) 13:447455.

40. Föllmann W, Weber S, Birkner S. primary cell cultures of bovine colon epithelium: isolation and cell culture of colonocytes. Toxicol In Vitro. (2000) 14:435-45. doi: 10.1016/S0887-2333(00)00033-3 
41. Chiba E, Villena J, Hosoya S, Takanashi N, Shimazu T, Aso H, et al. A newly established bovine intestinal epithelial cell line is effective for in vitro screening of potential antiviral immunobiotic microorganisms for cattle. Res Vet Sci. (2012) 93:688-94. doi: 10.1016/j.rvsc.2011.10.002

42. Rusu D, Loret S, Peulen O, Mainil J, Dandrifosse G. Immunochemical, biomolecular and biochemical characterization of bovine epithelial intestinal primocultures. BMC Cell Biol. (2005) 6:42. doi: 10.1186/1471-2121-6-42

43. Miyazawa K, Hondo T, Kanaya T, Tanaka S, Takakura I, Itani W, et al. Characterization of newly established bovine intestinal epithelial cell line. Histochem Cell Biol. (2010) 133:125-34. doi: 10.1007/s00418-009-0648-3

44. Birkner S, Weber S, Dohle A, Schmahl G, Föllmann W. Growth and characterisation of primary bovine colon epithelial cells in vitro. Altern Lab Anim. (2004) 32:555-71. doi: 10.1177/026119290403200607

45. Kaushik RS, Begg AA, Wilson HL, Aich P, Abrahamsen MS, Potter A, et al. Establishment of fetal bovine intestinal epithelial cell cultures susceptible to bovine rotavirus infection. J Virol Methods. (2008) 148:182-96. doi: 10.1016/j.jviromet.2007.11.006

46. Shimada N, Miyamoto K, Kanda K, Murata H. Binding of CrylAb Toxin, a bacillus thuringiensis insecticidal toxin, to proteins of the bovine intestinal epithelial cell: an in vitro study. Appl Entomol Zool. (2006) 41:295-301. doi: 10.1303/aez.2006.295

47. Zhan K, Yang TY, Chen Y, Jiang MC, Zhao GQ. Propionate enhances the expression of key genes involved in the gluconeogenic pathway in bovine intestinal epithelial cells. J Dairy Sci. (2020) 103:5514-24. doi: 10.3168/jds.2019-17309

48. An MJ, Cheon JH, Kim SW, Park JJ, Moon CM, Han SY, et al. Bovine colostrum inhibits nuclear factor $\kappa \mathrm{b}$-mediated proinflammatory cytokine expression in intestinal epithelial cells. Nutr Res. (2009) 29:275-80. doi: 10.1016/j.nutres.2009.03.011

49. Dziva F, Mahajan A, Cameron P, Currie C, McKendrick IJ, Wallis TS, et al. EspP, a Type V-secreted serine protease of enterohaemorrhagic Escherichia Coli O157:H7, influences intestinal colonization of calves and adherence to bovine primary intestinal epithelial cells. FEMS Microbiol Lett. (2007) 271:258-64. doi: 10.1111/j.1574-6968.2007.00724.x

50. Takanashi N, Tomosada Y, Villena J, Murata K, Takahashi T, Chiba E, et al. Advanced application of bovine intestinal epithelial cell line for evaluating regulatory effect of lactobacilli against heat-killed enterotoxigenic escherichia coli-mediated inflammation. BMC Microbiol. (2013) 13:54. doi: 10.1186/1471-2180-13-54

51. Yang Z, Fu Y, Gong P, Zheng J, Liu L, Yu Y, et al. Bovine TLR2 and TLR4 Mediate cryptosporidium parvum recognition in bovine intestinal epithelial cells. Microb Pathog. (2015) 85:29-34. doi: 10.1016/j.micpath.2015.05.009

52. Katwal P, Thomas M, Uprety T, Hildreth MB, Kaushik RS. Development and biochemical and immunological characterization of early passage and immortalized bovine intestinal epithelial cell lines from the ileum of a young calf. Cytotechnology. (2019) 71:127-48. doi: 10.1007/s10616-018-0272-y

53. Katwal P, Uprety T, Okda F, Antony L, Thomas M, Chase C, et al. Characterization of bovine ileal epithelial cell line for lectin binding, susceptibility to enteric pathogens, and TLR mediated immune responses. Comp Immunol Microbiol Infect Dis. (2021) 74:101581. doi: 10.1016/j.cimid.2020.101581

54. Kuroda K, Kiyono T, Isogai E, Masuda M, Narita M, Okuno K, et al. Immortalization of Fetal Bovine Colon Epithelial cells by expression of human cyclin $\mathrm{d} 1$, mutant cyclin dependent kinase 4 , and telomerase reverse transcriptase: an in vitro model for bacterial infection. PLOS ONE. (2015) 10:E0143473. doi: 10.1371/journal.pone.0143473

55. Immerseel FV, Buck JD, Smet ID, Pasmans F, Haesebrouck F, Ducatelle R. Interactions of butyric acid- and acetic acid-treated salmonella with chicken primary cecal epithelial cells in vitro. Avian Dis. (2004) 48:384-91. doi: 10.1637/7094

56. Dimier-Poisson IH, Bout DT, Quéré P. Chicken Primary enterocytes: inhibition of eimeria tenella replication after activation with crude interferon- $\gamma$ supernatants. Avian Dis. (2004) 48:617-24. doi: 10.1637/7180-031604R

57. Yuan C, He Q, Li J, Azzam MM, Lu J, Zou X. Evaluation of embryonic age and the effects of different proteases on the isolation and primary culture of chicken intestinal epithelial cells in vitro: primary culture of chicken IEC In vitro. Anim Sci J. (2015) 86:588-94. doi: 10.1111/asj.12337
58. Kaiser A, Willer T, Steinberg P, Rautenschlein S. Establishment of an in vitro intestinal epithelial cell culture model of avian origin. Avian Dis. (2017) 61:229-36. doi: 10.1637/11524-110216-Reg.1

59. Bai S, Zhang K, Ding X, Wang J, Zeng Q, Peng H, et al. Uptake of manganese from the manganese-lysine complex in primary chicken intestinal epithelial cells. Anim Open Access J MDPI. (2019) 9:559. doi: 10.3390/ani9080559

60. Bar Shira E, Friedman A. Innate immune functions of avian intestinal epithelial cells: response to bacterial stimuli and localization of responding cells in the developing avian digestive tract. PLoS ONE. (2018) 13:e0200393. doi: 10.1371/journal.pone.0200393

61. Rath NC, Liyanage R, Gupta A, Packialakshmi B, Lay JO. A method to culture chicken enterocytes and their characterization. Poult Sci. (2018) 18:248. doi: $10.3382 / \mathrm{ps} / \mathrm{pey} 248$

62. Ghiselli F, Rossi B, Felici M, Parigi M, Tosi G, Fiorentini L, et al. Isolation, culture, and characterization of chicken intestinal epithelial cells. BMC Mol Cell Biol. (2021) 22:12. doi: 10.1186/s12860-021-00349-7

63. Verhoeckx K, Cotter P, López-Expósito I, Kleiveland C, Lea T, Mackie A, et al. The Impact of Food Bioactives on Health. Cham: Springer International Publishing. (2015).

64. Xu H, Jiao Y, Qin S, Zhao W, Chu Q, Wu K. Organoid technology in disease modelling, drug development, personalized treatment and regeneration medicine. Exp Hematol Oncol. (2018) 7:40164. doi: 10.1186/s40164-018-0122-9

65. Barker N, van Es JH, Kuipers J, Kujala P, van den Born M, Cozijnsen M, et al. Identification of stem cells in small intestine and colon by marker gene Lgr5. Nature. (2007) 449:1003-7. doi: 10.1038/nature06196

66. Sato T, Stange DE, Ferrante M, Vries RGJ, Es JH. van, Brink S van den, Houdt WJ van, Pronk A, Gorp J van, Siersema PD, et al. Long-term expansion of epithelial organoids from human colon, adenoma, adenocarcinoma, and barrett's epithelium. Gastroenterology. (2011) 141:1762-72. doi: 10.1053/j.gastro.2011.07.050

67. Sato T, Vries RG, Snippert HJ, van de Wetering M, Barker N, Stange DE, et al. Single Lgr5 stem cells build crypt-villus structures in vitro without a mesenchymal niche. Nature. (2009) 459:262-5. doi: 10.1038/nature07935

68. Brierley AL. Organoids as an in vitro Model of Human Development and Disease. Nat Cell Biol. (1982) 18:24.

69. Takahashi T. Organoids for drug discovery and personalized medicine. Annu Rev Pharmacol Toxicol. (2019) 59:447-62. doi: 10.1146/annurev-pharmtox-010818-021108

70. Yu J, Peng S, Luo D, March JC. In Vitro 3D Human small intestinal villous model for drug permeability determination. Biotechnol Bioeng. (2012) 109:2173-8. doi: 10.1002/bit.24518

71. Braverman J, Yilmaz ÖH. From 3D Organoids Back to 2D Enteroids. Dev Cell. (2018) 44:533-4. doi: 10.1016/j.devcel.2018.02.016

72. Altay G, Larrañaga E, Tosi S, Barriga FM, Batlle E, Fernández-Majada $\mathrm{V}$, et al. Self-organized intestinal epithelial monolayers in crypt and villus-like domains show effective barrier function. Sci Rep. (2019) 9:497. doi: 10.1038/s41598-019-46497-x

73. Engevik AC, Coutts AW, Kaji I, Rodriguez P, Ongaratto F, Saqui-Salces M, Medida RL, Meyer AR, Kolobova E, Engevik MA, et al. editing myosin vb gene to create porcine model of microvillus inclusion disease, with microvillus-lined inclusions and alterations in sodium transporters. Gastroenterology. (2020) 158:2236-49. doi: 10.1053/j.gastro.2020.02.034

74. van der Hee B, Loonen LMP, Taverne N, Taverne-Thiele JJ, Smidt H, Wells JM. Optimized procedures for generating an enhanced, near physiological 2D culture system from porcine intestinal organoids. Stem Cell Res. (2018) 28:165-71. doi: 10.1016/j.scr.2018.02.013

75. Töpfer E, Pasotti A, Telopoulou A, Italiani P, Boraschi D, Ewart MA, et al. Bovine colon organoids: from 3D bioprinting to cryopreserved multi-well screening platforms. Toxicol In Vitro. (2019) 61:104606. doi: 10.1016/j.tiv.2019.104606

76. Resende TP, Medida RL, Vannucci FA, Saqui-Salces M, Gebhart C. Evaluation of swine enteroids as in vitro models for lawsonia intracellularis infection. J Anim Sci. (2020) 98:11. doi: 10.1093/jas/skaa011

77. Noel G, Baetz NW, Staab JF, Donowitz M, Kovbasnjuk O, Pasetti MF, et al. Primary human macrophage-enteroid co-culture model to investigate mucosal gut physiology and host-pathogen interactions. Sci Rep. (2017) 7:45270. doi: $10.1038 /$ srep 45270 
78. Fogh J. Human Tumor Cells in Vitro. New York, NY Springer. (1975).

79. Huet G, Kim I, de Bolos C, Lo-Guidice JM, Moreau O, Hemon B, Richet C, Delannoy P, Real FX, Degand P. Characterization of Mucins and Proteoglycans Synthesized by a Mucin-Secreting HT-29 Cell Subpopulation. J Cell Sci. (1995) 108(Pt 3):1275-1285. doi: 10.1242/jcs.108.3.1275

80. Arranz E, Guri A, Fornari T, Mendiola JA, Reglero G, Corredig M. In vitro uptake and immune functionality of digested rosemary extract delivered through food grade vehicles. Food Res Int. (2017) 97:71-7. doi: 10.1016/j.foodres.2017.03.033

81. Volstatova T, Marchica A, Hroncova Z, Bernardi R, Doskocil I, Havlik J. Effects of chlorogenic acid, epicatechin gallate, and quercetin on mucin expression and secretion in the caco-2/ht29-mtx cell model. Food Sci Nutr. (2019) 7:492-8. doi: 10.1002/fsn3.818

82. Schimpel C, Teubl B, Absenger M, Meindl C, Fröhlich E, Leitinger G, et al. development of an advanced intestinal in vitro triple culture permeability model to study transport of nanoparticles. Mol Pharm. (2014) 11:808-18. doi: $10.1021 / \mathrm{mp} 400507 \mathrm{~g}$

83. Antunes F, Andrade F, Araújo F, Ferreira D, Sarmento B. Establishment of a triple co-culture in vitro cell models to study intestinal absorption of peptide drugs. Eur J Pharm Biopharm Off $J$ Arbeitsgemeinschaft Pharm Verfahrenstechnik EV. (2013) 83:427-35. doi: 10.1016/j.ejpb.2012. 10.003

84. Araújo F, Sarmento B. Towards the characterization of an in vitro triple coculture intestine cell model for permeability studies. Int J Pharm. (2013) 458:128-34. doi: 10.1016/j.ijpharm.2013.10.003

85. Kleiveland CR. "Co-Culture Caco-2/Immune Cells," in The Impact of Food Bioactives on Health: In Vitro and ex Vivo Models, eds. K. Verhoeckx, P. Cotter, I. López-Expósito, C. Kleiveland, T. Lea, A. Mackie, T. Requena, D. Swiatecka, H. Wichers (Cham (CH): Springer). Available online at: https:// www.ncbi.nlm.nih.gov/books/NBK500163/ (accessed April 23, 2020).

86. Kämpfer AAM, Urbán P, Gioria S, Kanase N, Stone V, Kinsner-Ovaskainen A. Development of an in vitro co-culture model to mimic the human intestine in healthy and diseased state. Toxicol In Vitro. (2017) 45:31-43. doi: 10.1016/j.tiv.2017.08.011

87. Satsu H, Yokoyama T, Ogawa N, Fujiwara-Hatano Y, Shimizu M. The changes in the neuronal pc12 and the intestinal epithelial caco-2 cells during the coculture. Cytotechnology. (2001) 35:73-9. doi: 10.1023/A:1008136103927

88. Sadaghian Sadabad M, von Martels JZH, Khan MT, Blokzijl T, Paglia G, Dijkstra G, et al. Simple coculture system shows mutualism between anaerobic faecalibacteria and epithelial caco-2 cells. Sci Rep. (2015) 5:1-9. doi: $10.1038 /$ srep 17906

89. Agu RU, Ugwoke MI. “In Situ and Ex Vivo Nasal Models for Preclinical Drug Development Studies," in Drug Absorption Studies: In Situ, In Vitro and In Silico Models Biotechnology: Pharmaceutical Aspects., eds. C. Ehrhardt, K.-J. Kim (Boston, MA: Springer US), 112-134.

90. Ussing HH, Zerahn K. Active transport of sodium as the source of electric current in the short-circuited isolated frog skin. Acta Physiol Scand. (1951) 23:110-27. doi: 10.1111/j.1748-1716.1951.tb00800.x

91. Grass GM, Sweetana SA. In vitro measurement of gastrointestinal tissue permeability using a new diffusion cell. Pharm Res. (1988) 5:372-6. doi: 10.1023/A:1015911712079

92. Thomson A, Smart K, Somerville MS, Lauder SN, Appanna G, Horwood J, et al. The ussing chamber system for measuring intestinal permeability in health and disease. BMC Gastroenterol. (2019) 19:98. doi: 10.1186/s12876-019-1002-4

93. Westerhout J, Wortelboer H, Verhoeckx K. "Ussing Chamber," in The Impact of Food Bioactives on Health: In Vitro and ex Vivo Models, eds. K. Verhoeckx, P. Cotter, I. López-Expósito, C. Kleiveland, T. Lea, A. Mackie, T. Requena, D. Swiatecka, H. Wichers (Cham: Springer International Publishing), 263-273.

94. Wallon C, Braaf Y, Wolving M, Olaison G, Söderholm JD. Endoscopic biopsies in ussing chambers evaluated for studies of macromolecular permeability in the human colon. Scand J Gastroenterol. (2005) 40:586-95. doi: 10.1080/00365520510012235

95. Grilli E, Tugnoli B, Passey JL, Stahl CH, Piva A, Moeser AJ. Impact of dietary organic acids and botanicals on intestinal integrity and inflammation in weaned pigs. BMC Vet Res. (2015) 11:410. doi: 10.1186/s12917-0150410-0
96. Boudry G. The ussing chamber technique to evaluate alternatives to in-feed antibiotics for young pigs. Anim Res. (2005) 54:219-30. doi: 10.1051/animres:2005014

97. Lomasney KW, Hyland NP. The application of ussing chambers for determining the impact of microbes and probiotics on intestinal ion transport. Can J Physiol Pharmacol. (2013) 91:663-70. doi: 10.1139/cjpp-2013-0027

98. Amidon GL, Lee PI, Topp EM. Transport Processes in Pharmaceutical Systems. London: CRC Press. (1999).

99. Ferruzza S, Rossi C, Sambuy Y, Scarino ML. Serum-reduced and serum-free media for differentiation of Caco-2 Cells. ALTEX - Altern Anim Exp. (2013) 30:159-68. doi: 10.14573/altex.2013.2.159

100. Béduneau A, Tempesta C, Fimbel S, Pellequer Y, Jannin V, Demarne F, et al. Tunable Caco-2/HT29-MTX co-culture model mimicking variable permeabilities of the human intestine obtained by an original seeding procedure. Eur J Pharm Biopharm Off J Arbeitsgemeinschaft Pharm Verfahrenstechnik EV. (2014) 87:290-8. doi: 10.1016/j.ejpb.2014.03.017

101. Bazes A, Nollevaux G, Coco R, Joly A, Sergent T, Schneider Y-J. Development of a triculture based system for improved benefit/risk assessment in pharmacology and human food. BMC Proc. (2011) 5 Suppl 8:P67. doi: 10.1186/1753-6561-5-S8-P67

102. Hillgren KM, Kato A, Borchardt RT. In vitro systems for studying intestinal drug absorption. Med Res Rev. (1995) 15:83-109. doi: 10.1002/med.2610150202

103. Ungell A-L. In vitro absorption studies and their relevance to absorption from the GI tract. Drug Dev Ind Pharm. (1997) 23:879-92. doi: $10.3109 / 03639049709148694$

104. Le Ferrec E, Chesne C, Artusson P, Brayden D, Fabre G, Gires $\mathrm{P}$, et al. In Vitro models of the intestinal barrier: the report and recommendations of ECVAM Workshop 46. Altern Lab Anim. (2001) 29:649-68. doi: 10.1177/026119290102900604

105. Lecce JG. In Vitro Absorption of $\gamma$-globulin by neonatal intestinal epithelium of the pig. J Physiol. (1966) 184:594-604. doi: 10.1113/jphysiol.1966.sp007933

106. Pierce AE, Smith MW. The in vitro transfer of bovine immune lactoglobulin across the intestine of new-born pigs. J Physiol. (1967) 190:19-34. doi: 10.1113/jphysiol.1967.sp008190

107. Voortman T, Hendriks HFJ, Witkamp RF, Wortelboer HM. Effects of longand short-chain fatty acids on the release of gastrointestinal hormones using an ex vivo porcine intestinal tissue model. J Agric Food Chem. (2012) 60:9035-42. doi: 10.1021/jf2045697

108. Roeselers G, Ponomarenko M, Lukovac S, Wortelboer HM. Ex Vivo systems to study host-microbiota interactions in the gastrointestinal tract. Best Pract Res Clin Gastroenterol. (2013) 27:101-13. doi: 10.1016/j.bpg.2013. 03.018

109. Westerhout J, Steeg E. van de, Grossouw D, Zeijdner EE, Krul CAM, Verwei M, Wortelboer HM. A new approach to predict human intestinal absorption using porcine intestinal tissue and biorelevant matrices. Eur J Pharm Sci. (2014) 63:167-77. doi: 10.1016/j.ejps.2014.07.003

110. Ripken D, van der Wielen N, Wortelboer HM, Meijerink J, Witkamp RF, Hendriks HFJ. Nutrient-Induced Glucagon Like Peptide-1 Release Is Modulated by Serotonin. J Nutr Biochem. (2016) 32:142-50. doi: 10.1016/j.jnutbio.2016.03.006

111. Witkamp RF. The role of fatty acids and their endocannabinoid-like derivatives in the molecular regulation of appetite. Mol Aspects Med. (2018) 64:45-67. doi: 10.1016/j.mam.2018.01.002

112. Gonzalez LM, Williamson I, Piedrahita JA, Blikslager AT, Magness ST. Cell Lineage Identification and stem cell culture in a porcine model for the study of intestinal epithelial regeneration. PLoS ONE. (2013) 8:66465. doi: 10.1371/journal.pone.0066465

113. Forsgård R. Intestinal permeability as a marker of gastrointestinal health. Cancer Chemother Pharmacol. (2016) 78:863-74. doi: 10.1007/s00280-016-3150-3

114. Ghaffarian R, Muro S. Models and methods to evaluate transport of drug delivery systems across cellular barriers. J Vis Exp JoVE. (2013) 506:38. doi: $10.3791 / 50638$

115. Jejunal Permeability: A Comparison Between the Ussing Chamber Technique and the Single-Pass Perfusion in Humans - ProQuest. Available online at: 
https://www.proquest.com/Docview/222658829?pq-Origsite $\$=\$$ Gscholar (accessed April 22, 2020).

116. Hubatsch I, Ragnarsson EGE, Artursson P. Determination of drug permeability and prediction of drug absorption in Caco-2 monolayers. Nat Protoc. (2007) 2:2111-9. doi: 10.1038/nprot.2007.303

117. Galipeau HJ, Verdu EF. The complex task of measuring intestinal permeability in basic and clinical science. Neurogastroenterol Motil. (2016) 28:957-65. doi: 10.1111/nmo.12871

118. Liu J, Teng P-Y, Kim WK, Applegate TJ. Assay Considerations for fluorescein isothiocyanate-dextran (FITC-d): an indicator of intestinal permeability in broiler chickens. Poult Sci. (2021) 100:101202. doi: 10.1016/j.psj.2021.101202

119. A Guide to Ussing Chamber Studies of Mouse Intestine|American Journal of Physiology-Gastrointestinal and Liver Physiology. Available online at: https://journals.physiology.org/doi/full/10.1152/ajpgi.90649.2008 (accessed September 28, 2021).

120. Azizi PM, Zyla RE, Guan S, Wang C, Liu J, Bolz S-S, et al. Clathrindependent entry and vesicle-mediated exocytosis define insulin transcytosis across microvascular endothelial cells. Mol Biol Cell. (2015) 26:740-50. doi: 10.1091/mbc.E14-08-1307

121. Thomas A, Wang S, Sohrabi S, Orr C, He R, Shi W, et al. Characterization of vascular permeability using a biomimetic microfluidic blood vessel model. Biomicrofluidics. (2017) 11:024102. doi: 10.1063/1.4977584

122. Michael Danielsen E, Hansen GH. Small Molecule pinocytosis and clathrin-dependent endocytosis at the intestinal brush border: two separate pathways into the enterocyte. Biochim Biophys Acta. (2016) 1858:233-43. doi: 10.1016/j.bbamem.2015.11.022

123. Srinivasan B, Kolli AR, Esch MB, Abaci HE, Shuler ML, Hickman JJ, et al. Measurement techniques for in vitro barrier model systems. J Lab Autom. (2015) 20:107-26. doi: 10.1177/2211068214561025

124. Palumbo P, Lombardi F, Cifone MG, Cinque B. The epithelial barrier model shows that the properties of vsl\#3 depend from where it is manufactured. Endocr Metab Immune Disord Drug Targets. (2019) 19:199-206. doi: 10.2174/18715303186661810221 64505

125. Linnankoski J, Mäkelä J, Palmgren J, Mauriala T, Vedin C, Ungell AL, et al. Paracellular porosity and pore size of the human intestinal epithelium in tissue and cell culture models. J Pharm Sci. (2010) 99:2166-75. doi: 10.1002/jps.21961

126. Van Itallie CM, Fanning AS, Bridges A, Anderson JM. ZO-1 stabilizes the tight junction solute barrier through coupling to the perijunctional cytoskeleton. Mol Biol Cell. (2009) 20:3930-40. doi: 10.1091/mbc.e09-04-0320

127. Masereeuw R, Moons MM, Toomey BH, Russel FGM, Miller DS. Active lucifer yellow secretion in renal proximal tubule: evidence for organic anion transport system crossover. J Pharmacol Exp Ther. (1999) 289:1104-11.

128. Paszti-Gere E, Barna RF, Kovago C, Szauder I, Ujhelyi G, Jakab $\mathrm{C}$, et al. Changes in the distribution of type ii transmembrane serine protease, TMPRSS2 and in paracellular permeability in ipecj2 cells exposed to oxidative stress. Inflammation. (2015) 38:775-83. doi: 10.1007/s10753-014-9988-9

129. Bein A, Zilbershtein A, Golosovsky M, Davidov D, Schwartz B, LPS. Induces hyper-permeability of intestinal epithelial cells: LPS induces hyper-permeability of intestinal cells. J Cell Physiol. (2016) 232:25435. doi: $10.1002 /$ jcp. 25435

130. González-González M, Díaz-Zepeda C, Eyzaguirre-Velásquez J, González-Arancibia C, Bravo JA, Julio-Pieper M. Investigating gut permeability in animal models of disease. Front Physiol. (2019) 9:1962. doi: 10.3389/fphys.2018.01962

131. Hickman J. Transepithelial/endothelial electrical resistance (TEER) theory and applications for microfluidic body-on-a-chip devices. J Rare Dis Res Treat. (2016) 1:46-52. doi: 10.29245/2572-9411/2016/3.1026

132. Benson K, Cramer S, Galla H-J. Impedance-based cell monitoring: barrier properties and beyond. Fluids Barriers CNS. (2013) 10:5. doi: 10.1186/2045-8118-10-5

133. Kawauchiya T, Takumi R, Kudo Y, Takamori A, Sasagawa T, Takahashi K, et al. Correlation between the destruction of tight junction by patulin treatment and increase of phosphorylation of zo-1 in Caco- 2 human colon cancer cells. Toxicol Lett. (2011) 205:196-202. doi: 10.1016/j.toxlet.2011.06.006
134. Amsen D, de Visser KE, Town T. Approaches to determine expression of inflammatory cytokines. Methods Mol Biol Clifton NJ. (2009) 511:107-42. doi: 10.1007/978-1-59745-447-6_5

135. Anderson JM, Van Itallie CM. Physiology and function of the tight junction. Cold Spring Harb Perspect Biol. (2009) 1:2584. doi: 10.1101/cshperspect.a002584

136. Colegio OR, Van Itallie C, Rahner C, Anderson JM. Claudin extracellular domains determine paracellular charge selectivity and resistance but not tight junction fibril architecture. Am J Physiol Cell Physiol. (2003) 284:C1346-1354. doi: 10.1152/ajpcell.00547.2002

137. Tervonen A, Ihalainen TO, Nymark S, Hyttinen J. Structural dynamics of tight junctions modulate the properties of the epithelial barrier. PLOS ONE. (2019) 14:14876. doi: 10.1371/journal.pone.0214876

138. Suzuki T, Tanabe S, Hara H. Kaempferol Enhances intestinal barrier function through the cytoskeletal association and expression of tight junction proteins in Caco-2 cells. J Nutr. (2010) 141:87-94. doi: 10.3945/jn.110.125633

139. Watson CJ, Hoare CJ, Garrod DR, Carlson GL, Warhurst G. Interferongamma selectively increases epithelial permeability to large molecules by activating different populations of paracellular pores. J Cell Sci. (2005) 118:5221-30. doi: 10.1242/jcs.02630

140. Holland TM, Agarwal P, Wang Y, Leurgans SE, Bennett DA, Booth SL, Morris MC. Dietary Flavonols and Risk of Alzheimer Dementia. Neurology. (2020)10.1212/WNL.0000000000008981. doi: 10.1212/WNL.0000000000008981

141. Endo S, Matsuoka T, Nishiyama T, Arai Y, Kashiwagi H, Abe N, et al. Flavonol glycosides of rosa multiflora regulates intestinal barrier function through inhibiting claudin expression in differentiated Caco-2 Cells. Nutr Res. (2019) 72:92-104. doi: 10.1016/j.nutres.2019.10.010

142. Mani V, Rubach JK, Sanders DJ, Pham T, Koltes DA, Gabler NK, et al. Evaluation of the protective effects of zinc butyrate in Ipec-j2 cells and grower pigs under heat stress1. Transl Anim Sci. (2019) 3:842-54. doi: $10.1093 /$ tas/txz023

143. Briske-Anderson MJ, Finley JW, Newman SM. The influence of culture time and passage number on the morphological and physiological development of Caco-2 Cells. Proc Soc Exp Biol Med Soc Exp Biol Med N Y N. (1997) 214:248-57. doi: 10.3181/00379727-214-44093

144. Sala FG, Kunisaki SM, Ochoa ER, Vacanti J, Grikscheit TC. Tissueengineered small intestine and stomach form from autologous tissue in a preclinical large animal model. J Surg Res. (2009) 156:205-12. doi: $10.1016 /$ j.jss.2009.03.062

145. Pearce SC, Coia HG, Karl JP, Pantoja-Feliciano IG, Zachos NC, Racicot K. Intestinal in vitro and ex vivo models to study hostmicrobiome interactions and acute stressors. Front Physiol. (2018) 9:1584. doi: 10.3389/fphys.2018.01584

146. Jafari NV, Kuehne SA, Minton NP, Allan E, Bajaj-Elliott M. Clostridium difficile-mediated effects on human intestinal epithelia: modelling hostpathogen interactions in a vertical diffusion chamber. Anaerobe. (2016) 37:96-102. doi: 10.1016/j.anaerobe.2015.12.007

147. Seeger B. Farm animal-derived models of the intestinal epithelium: recent advances and future applications of intestinal organoids. Altern Lab Anim ATLA. (2020) 48:215-33. doi: 10.1177/0261192920974026

148. Tsuruta S, Uchida H, Akutsu H. Intestinal organoids generated from human pluripotent stem cells. JMA J. (2020) 3:9-19. doi: 10.31662/jmaj.2019-0027

149. Kumar D, Talluri TR, Selokar NL, Hyder I, Kues WA. Perspectives of pluripotent stem cells in livestock. World J Stem Cells. (2021) 13:1-29. doi: 10.4252/wjsc.v13.i1.1

Conflict of Interest: BR was employed by company Vetagro S.p.A. AP and EG serves in the board of Directors of Vetagro S.p.A.

The remaining authors declare that the research was conducted in the absence of any commercial or financial relationships that could be construed as a potential conflict of interest.

Publisher's Note: All claims expressed in this article are solely those of the authors and do not necessarily represent those of their affiliated organizations, or those of the publisher, the editors and the reviewers. Any product that may be evaluated in 
this article, or claim that may be made by its manufacturer, is not guaranteed or endorsed by the publisher.

Copyright $\odot 2021$ Ghiselli, Rossi, Piva and Grilli. This is an open-access article distributed under the terms of the Creative Commons Attribution License (CC BY).
The use, distribution or reproduction in other forums is permitted, provided the original author(s) and the copyright owner(s) are credited and that the original publication in this journal is cited, in accordance with accepted academic practice. No use, distribution or reproduction is permitted which does not comply with these terms. 